九州大学学術情報リポジトリ

Kyushu University Institutional Repository

The Magnitude of Population And Fishing Rate Of King-Crab, Paralithodes Camtschatica (Tilesius)

Aikawa, Hiroaki

Fisheries Laboratry, Department of Agriculture, Kyusyu University

https://doi.org/10.5109/22607

出版情報: 九州大学大学院農学研究院紀要. 9 (1)，pp.41-49，1948-03. Kyushu University バージョン：

権利関係 : 


\title{
THE MAGNITUDE OF POPULATION AND FISHING RATE OF KING-CRAB, PARALITHODES \\ CAMTSCHATICA (TILESIUS)
}

\author{
HIrROAKI AIKAWA
}

The Sakhalin district, extending from both coast of southern Sakhalin to the Okhotsk coast of Hokkaidô, the Nemuro district around the southern Kurile Islands to Kushiro along the Pacific coast of Hokkaidô, and the Kamrchatka district, especially off its west coast, are 3 important fishing grounds for the Japanese Kingcrab fishery. The crab populations of these districts are respectively of different magnitude and also of different race, being distinguishable by their morphological features. Here, the magnitude and fishing rate are computed statistically for the populations in the Nemuro and Kamtchatka districts.

1. Larval death rate and natural decreasing rates of matured groups

From the epoch-making investigation of Dr. Marukawa (1933), it is known that the larval death rate is catastrophically as high as 0.97 during the period from the 1st. zoea stage, just after hatched out from berried crab, to the youngest crab stage through glaucothoe stage, so that only $3 \%$ of the 1st. zoea larvae can survive, till they attain the smallest adult form. These youngest crabs must undergo furthermore remarkable decrease through 7 or 9 moultages, till they grow $7 \mathrm{~mm}$ in carapace width in the next Spring. As the decreasing rate is 0.16 on an average at each 
moultage, the total decreasing rate of $\mathrm{O}$-age group is at least $0.99977=1-(1-0.964)(1-0.16)^{\circ}$

On examining the frequency distributions of carapace width, Marukawa considered the isolated dominant size groups to be of different ages. Thence, the matured crabs of $10 \mathrm{~cm}$ or thereabouts in carapace width are supposed to be at least of 8 -age. Y. Kajita (1932) however observed in the Nemuro district that the matured crabs were at most of 4-age and already attained the size above $10 \mathrm{~cm}$, and Wang (1937) was also of opinion that in the Sakhalin district the matured groups were of 3-and 4-age, and those of 4-age were larger than $17 \mathrm{~cm}$. Therefore, the same age group is certainly composed of some isolated size groups, which are different in the number of moultages from each other.

From Wang's data, it is known that the minimum size of $\mathrm{N}$-age group is $1_{n} \mathrm{~cm}$ in carapace width and that of $(\mathrm{N}+1)$-age group $1_{n, 1} \mathrm{~cm}$. On the other hand, from Dr. Marukawa's data, the minimum size of $(\mathrm{N}+\mathrm{x})$-age group is nearly equal to $1_{n} \mathrm{~cm}$ and that of $(\mathrm{N}+\mathrm{x}+\mathrm{y})$-age group also to $1_{n+1} \mathrm{~cm}$. Then, $(\mathrm{N}+\mathrm{x}$ $+\mathrm{y})-(\mathrm{N}+\mathrm{x})=\mathrm{y}$ is the number of moultages, which $\mathrm{N}$-age group undergoes during a year, and after which it becomes a year older. The natural decreasing rate, mainly due to the moultage, is computable as $1-(1-0.16)^{y}$. The accuracy of these natural decreasing rates computed must be ascertained with other data.

Table 1. Age, number of moultages, and computed decreasing rate of king-crab, Paralithodes comtschatica.

\begin{tabular}{|c|c|c|c|c|c|c|c|c|}
\hline \multicolumn{5}{|c|}{ Marukawa (1933) } & \multicolumn{4}{|c|}{ Wang (1937) } \\
\hline \multirow{2}{*}{ Age } & \multicolumn{2}{|c|}{ Size (nm) } & \multirow{2}{*}{$\begin{array}{l}\text { No. of } \\
\text { moult- } \\
\text { ages }\end{array}$} & \multirow{2}{*}{$\begin{array}{l}\text { Decreas } \\
\text { ing rate } \\
(m)\end{array}$} & \multirow{2}{*}{ Age } & \multirow{2}{*}{$\begin{array}{l}\text { Size } \\
\text { immu) }\end{array}$} & \multirow{2}{*}{$\begin{array}{l}\text { No. of } \\
\text { moult } \\
\text { ages }\end{array}$} & \multirow{2}{*}{$\begin{array}{l}\text { Decreas. } \\
\text { ing rate } \\
(m)\end{array}$} \\
\hline & 3 & $\varnothing$ & & & & & & \\
\hline Zoëa & & - & 4 & 0.964 & & & & \\
\hline Glaucothë & & - & $i$ & 0.16 & & & & \\
\hline Young crab & & 7 & 8 & 0.749 & & & & \\
\hline$v$-age & & 7 & 13 & 0.998 & & & & \\
\hline 1 & & 7 & 6.5 & 0.69 & & & & \\
\hline 2 & & 25 & $"$ & $"$ & & & & \\
\hline 3 & & 34 & 2.5 & 0.35 & & & & \\
\hline 4 & & 2 & $"$. & is & & & & \\
\hline 5 & & 3 & 2 & 0.294 & 0 -age & $<51$ & 33 & $0.99977^{\circ}$ \\
\hline
\end{tabular}




\begin{tabular}{|c|c|c|c|c|c|c|c|c|}
\hline f-age & \multicolumn{2}{|c|}{70} & $"$ & " & & & & \\
\hline 7 & \multicolumn{2}{|c|}{85} & " & " & 1 & 101 & b & 0.649 \\
\hline 8 & \multicolumn{2}{|c|}{100} & " & " & & & & \\
\hline 9-age & 130 & 11.6 & 1 & 0.16 & & & & \\
\hline 10 & 132 & 125 & " & " & 2 & 145 & 4 & 0.502 \\
\hline 11 & 142 & 130 & " & "' & & & & \\
\hline 12-age & 150 & 135 & " & " & & & & \\
\hline 13 & 157 & 140 & " & " & & & & \\
\hline 14 & 167 & 144 & " & . & 3 & 170 & 4 & 0.502 \\
\hline 15 & 171 & 148 & " & " & & & & \\
\hline 16-age & 175 & 151 & 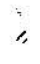 & " & & & & \\
\hline 17 & 179 & 153 & " & " & & & & \\
\hline 18 & 183 & 155 & " & " & 4 & 190 & 4 & 0.502 \\
\hline 19 & 186 & 157 & " & $"$ & & & & \\
\hline 20 & 189 & 160 & " & " & & & & \\
\hline 21-age & 191 & 162 & " & " & & & & \\
\hline 22 & 193 & 164 & " & " & & & & \\
\hline 23 & 198 & 166 & " & $"$ & 5 & 204 & 4 & 0.502 \\
\hline 24 & 201 & - & $"$ & " & & & & \\
\hline 25 & & - & " & $"$ & & & & \\
\hline
\end{tabular}

Note: Average number of moultages assu $x_{x}$ led as 4 for the groups older than 1-age.

2. The magnitude of population and fishing rate in the Nemuro district

In the Nemuro district, the production of canned crabs amounted to $51 \times 10^{3}$ cases on an average and showed no remarkable fluctuation recently. Then, the population must be balanced with fishing intensity and the annual recruitment amount might be equal to the annual yield of crabs. $51 \times 10^{3}$ cases correspond to $1200 \times 10^{3}$ male crabs. The female crabs may be caught together with gill-nets, but they are usually liberated at once into water. But, most of them die and cannot survive long, as the gill-nets are lifted a few days after being set in water. So, fernale crabs which were caught must be added to the decrease in population 
due to fishing, As female crabs occupy $36 \%$ of the shoal, the loss of female crabs is about $670 \times 10^{3}$ individuals, and, thus, the total decrease is $1870 \times 10^{3}$ individuals, which must be equal to the annual recruitment amount here.

Now, 4-age crabs, ranging from $17 \mathrm{~cm} 1019 \mathrm{~cm}$ in carapace width, are dominant in the Nemuro district and the female crabs of 4-age can produce $200 \times 10^{3}$ zoëa larvat on an average. Then, the number of female crabs $(R)$, which can supply the recruitment with $1870 \times 10^{3}$ crabs after 4 years, is

$$
\begin{aligned}
R & =-\frac{1870 \times 10^{3}}{200 \times 10^{3}(1-0.99977)(1-0.649)(1-0.502)^{2}} \\
& =47 \times 10^{3} \text { individuals (female crabs only) }
\end{aligned}
$$

$47 \times 10^{3} / 0.36=131 \times 10^{3}$ individuals (male crabs included) are the total number of crabs, which must be left unfished. Then, at the beginning of the fishing season, $2000 \times 10^{3}\left(=1870 \times 10^{3}+131 \times 10^{3}\right)$ crabs must migrate into the Nemuro district. In addition to this 4-age group, 2- and 3- age groups must migrate here and their amounts are respectively

3-age group $2000 \times 10^{3} /(1-0.502)=4016 \times 10^{3}$ individuals

2-age group $2000 \times 10^{3} /(1 \cdots 0.502)^{2}=8064 \times 10^{3}$ individuals

Then, the total spawning shoal will amount to $14080 \times 10^{3}$ individuals. This is the magnitude of population in the Nemuro district. Then, the fishing rate $(f)$ is

$$
f=F=\frac{1870 \times 10^{3}}{S}=0.135
$$

In the Nemuro district, 390 tagged crabs were liberated and 22 crabs were recaptured within the same fishing season, then the recapture rate $(r)$ is $0.056(22 / 390)$. For the calculation of fishing rate, the recapture rate must be corrected not only with time factor but also with catch factor. The fishing, rate is usually $3.5 \times r$ or thereabouts. Then, the fishing rate will never be smaller then 0.196 , which is somewhat larger than the rate calculated statistically, so that the decreasing rate of the matured crabs, considered as 0.502 , will be rather smaller than the real rate. Therefore, the magnitude of population will be far smaller than $14000 \times 10^{3}$ individuals here. 
3. The magnitude of population and fishing rate in the Kamtchatka district

Here, the yield of King-crabs was rather small from the tactories installed on land. While, after the fishing experiment during the years from 1914 to 1920 , crab fishery with floating factory has been carried out with success since 1923. From the relation between the annual yield $(\boldsymbol{F})$ and the number of gill-nets used $(n)$, the following 3 equations are established (see fig. 1)

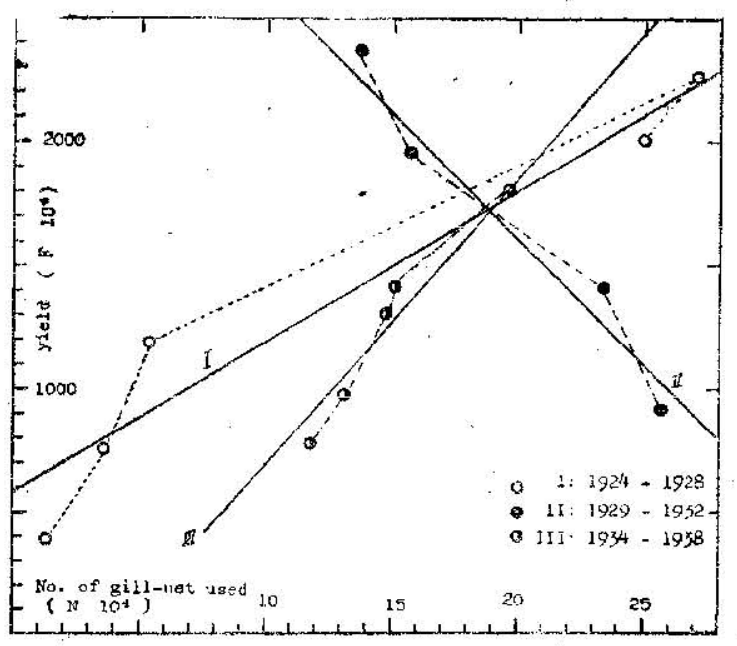

Fig. 1. Relation between the annual yicld and the number of gill-net used (see table 2).

$$
\begin{array}{ll}
1924-' 26 \text { (1st period) } & F=462 \times 10^{4}+103 \cdot n \\
1929-32 \text { (2nd period) } & F=3671 \times 10^{4}-104 \cdot n \\
1934-38 \text { (3rd period) } & F=-429 \times 10^{4}-114 \cdot n
\end{array}
$$

During the 1st period, 1924-'28, the annual yield increased in accordance with the increase in the number of gill-nets used, while, during the 2nd period, 1929-'32, the annual yield decreased inversely with the increase in the number of gill-nets used, but during the 3rd period, 1934-'38, the relation between them became again the same as that during the 1st period.

When $k$ is the fishing intensity of an unit fishing effort of gill-net, $S$ the magnitude of population and $F$ the annual 
yield, the following equation can be obtained, as far as the gill net is the competitive gear

$$
F=S\left\{1-(1-k)^{n}\right\}
$$

where $n$ is the number of unit fishing efforts. When $n$ is large enough to be considered that $n \cdot(n-1)$ is nearly equal to $n^{2}$ and, in addition, $k$ is very small in value, the equation above is

$$
F=S \cdot n \cdot k-S \cdot n^{2} \cdot k^{2} / 2
$$

From cquations 1 and $2^{\prime}$, the fishing intensity $(k)$ is computable indepently from $S$ and $n$. The $k$-value was $-0.446 \times 10^{-4}$ during the 1st. period, when the increase in the magnitude of available population exceeded considerably the decrease due to fishing mortality. On the contrary, $k$-values became positive in the succeeding periods, being $0.057 \times 10^{-4}$ during the 2 nd. period and 0.531 $\times 10^{-4}$ during the $3 \mathrm{rd}$, as the total population here became available since 1929 . The $k$-values were considerably different from each other, as the magnitudes of population varied. From equation $\left(2^{\prime}\right)$, the fishing rate $(f)$ is

$$
f=\frac{F}{S} \fallingdotseq k \cdot n-\frac{1}{2} k^{2} \cdot n^{2}
$$

and also the magnitude of population $(S)$ is

$$
S=\frac{F}{f}-\frac{F}{k \cdot n-1 / 2 k^{2} \cdot n^{2}}
$$

To these equations, the known values of $n$ and $k$ are substituted, then, $f$ and $S$ are calculated as shown in table 2, where $k$-value in the 1st. period is assumed to be similar to that in the 3rd. period.

Table 2. Statistical table for king crab fishery in the Kamtchatka district

\begin{tabular}{ccrrrrrr}
\hline Year & $\begin{array}{c}\text { No. of } \\
\text { float. } \\
\text { fact. }\end{array}$ & $\begin{array}{c}\text { No. of } \\
\text { unit fish. } \\
\text { efforts }\end{array}$ & $\begin{array}{c}\text { Annual } \\
\text { yield } \\
\left(f \times 10^{3}\right)\end{array}$ & $\begin{array}{c}\text { No. of individuals } \\
\text { effort }\end{array}$ & $\begin{array}{c}\text { per } \\
\text { a case }\end{array}$ & $\begin{array}{c}\text { Fishig } \\
\text { rate } \\
(f)\end{array}$ & $\begin{array}{c}\text { Calculated } \\
\text { magnitude } \\
\left(S \times 10^{3}\right)\end{array}$ \\
\hline 1924 & 6 & 12770 & 3930 & 48.05 & 96.1 & 0.070 & 56143 \\
1925 & 8 & 35546 & 7648 & 31.69 & 72.5 & 0.181 & 42254 \\
1926 & 12 & 54251 & 13873 & 21.25 & 63.3 & 0.260 & 53358 \\
1927 & 17 & 271273 & 22643 & 22.00 & 68.5 & 0.355 & 63747 \\
1928 & 14 & 249871 & 20113 & 14.83 & 66.2 & 0.414 & 48583 \\
mean & - & - & - & 27.54 & 73.3 & 0.256 & 52819
\end{tabular}




\begin{tabular}{cccccccc}
1929 & 15 & 137005 & 23718 & 10.83 & 64.7 & 0.476 & 49828 \\
1930 & 13 & 147159 & 19571 & 9.83 & 57.9 & 0.487 & 40187 \\
1931 & 8 & 233521 & 14141 & 7.52 & 66.4 & 0.545 & 25947 \\
1932 & 6 & 256572 & 9186 & 5.95 & 68.2 & 0.373 & 24627 \\
1933 & 5 & - & 6624 & - & 63.7 & - & - \\
mean & - & - & - & 8.53 & 64.2 & 0.470 & 35147 \\
1934 & 5 & 118000 & 7788 & 6.59 & 67.5 & 0.428 & 18196 \\
1935 & 6 & 131000 & 9800 & 7.54 & 69.7 & 0.443 & 22124 \\
1936 & 7 & 148400 & 13084 & 8.80 & 79.0 & 0.469 & 27898 \\
1937 & - & 152400 & 14194 & 9.30 & 76.2 & 0.473 & 30008 \\
1938 & - & 196400 & 18055 & 9.20 & 75.2 & 0.500 & 36110 \\
mean & - & - & - & 8.29 & 73.5 & 0.463 & 26867 \\
\hline
\end{tabular}

During the 1st. period, the magnitude of population remained unchanged, being $52819 \times 13^{3}$ individuals on an average, despite that the number of gill-nets used and the fishing rate increased. During the 2nd period, however, the magnitude of population decreascd year by year with the increase in the number of gillnets used and also in the fishing rate. Thence, we must consider that the population is being overfished according to the definition given by E. S. Russel (1939). The catch per unit fishing effort became less than one third of that in the preceding period, although the number of individuals required for a case of canned crabs remained unchanged. In the 3 rd. period, the magnitude of population became again large according to the increase in the number of gill-nets used and also in the fishing rate. However, the catch per unit fishing effort. and the number of individuals required for a case of canned crabs increased, so that the population would never be replenished with sufficient amount, and it would include smaller crabs within it than before. In other words, the small crabs of 2- and 3- age became more available in the 3rd. period than in the previous period. Accordingly, the fishing was furthermore intensified.

Recently, the magnitude of population may be replenished due to the closure for several years during the World War II, and may attain the previous stationary population, $5000 \times 10^{3}$ individuals, as was seen in the 1st. period.

Among the liberated crabs in 1928, 220 tagged ones were 
caught within the same fishing season, 96 in 1929 and lastly 8 in 1930. Then, the total decreasing rate $(d)$ is computed with Tauti's formula

$$
1-d=\frac{96+8}{220 \times 2+96+8}=1-0.795
$$

As the average fishing rate during the years 1930 is 0.459 (see table 2), the natural decreasing rate $(m)$ is computable by the equation below

$$
1-d=(1-f)(1-m)
$$

then, $1-m=1-0.646$. This $m$-value is approximately similar to that of 2-age group (0.649) and also that of 3- age and older age groups (0.502).

The tagging experiment was tried again in 1929. Tagged crabs were liberated every month during the fishing season and some of them were also recaptured within the same season. When $T$ is the whole duration of fishing season, $T_{n}$ the duration from the month of liberation to the end of season, $F$ the total catch during $T$ and $F_{n}$ during $T_{n}$, the efficiency of liberation of $X_{n}$ crabs at $T_{n}$ is equivalent to that of $\bar{X}_{n} \cdot T_{n} / T \cdot F_{n} / \bar{F}=\bar{X}_{n}{ }^{\prime}$ at the beginning of the fishing season. Then the fishing rate $(f)$ is

$$
f=\frac{x}{X_{n} \cdot T_{n} / T \cdot F_{n} / F}=\stackrel{x}{X^{\prime}}\left(\frac{T}{T_{n}} \cdot \underset{F}{F_{n}}\right)=r^{\prime}\left(\frac{T}{T_{n}} \frac{F}{F_{n}}\right) \ldots \ldots
$$

where $x$ is the number of recaptured crabs, $T_{n} / T$ the time factor and $F_{n} / F$ the catch factor. $F_{n_{i}}, T_{n}$ and $\sum_{l}^{n} X_{n}^{\prime}\left(=X^{\prime}\right)$ are shown in tables 3 and 4. The fishing rate is 0.458 in 1928 and 0.335 in 1929, both being approximately equal to $f$-values obtained statistically

\begin{tabular}{|c|c|c|c|c|c|c|c|}
\hline Year & Month & $\begin{array}{c}\text { No. of } \\
\text { liberated } \\
\text { individuals }\end{array}$ & $\begin{array}{l}\text { Time } \\
\text { factor } \\
T / T_{n}\end{array}$ & $\begin{array}{l}\text { Catch } \\
\text { facter } \\
F / F_{n}\end{array}$ & $\begin{array}{l}\text { No. of } \\
\text { recap. } \\
\text { indiv. }\end{array}$ & $\begin{array}{c}\text { Do. } \\
\text { corrected } \\
\left(x^{\prime}\right)\end{array}$ & $\begin{array}{l}\text { Fishing } \\
\text { rate } \\
(f)\end{array}$ \\
\hline \multirow[t]{3}{*}{1928} & VI & 500 & 1.71. & 1.43 & 109 & 207 & \\
\hline & VII & 500 & 2.40 & 2.56 & 41 & 251 & \\
\hline & Sum & 1000 & - & - & 150 & 458 & 0.458 \\
\hline \multirow[t]{5}{*}{1929} & V & 77 & 1.33 & 1.09 & 14 & 22 & \\
\hline & $\mathrm{VI}$ & 164 & 1.71 & 1.43 & 17 & $4 \%$ & \\
\hline & VII & 171 & 2.40 & 2.56 & 12 & 74 & \\
\hline & VIII & 1 & 4.00 & 7.69 & 0 & 0 & \\
\hline & Sum & 413 & - & - & 43 & 138 & 0.335 \\
\hline
\end{tabular}
(see table 2).

Table 3. Tagging experiments and factors of correction 
Table 4. Montly change in catch

\begin{tabular}{cccccccc}
\hline Year & Apr. & May & June & July & Aug. & Sept. \\
\hline 1927 & - & 9.6 & 38.6 & 29.0 & 22.8 & - \\
1928 & 2.9 & 11.2 & 30.6 & 48.9 & 6.0 & 0.4 \\
1929 & - & 21.7 & 17.4 & 13.0 & 39.2 & 8.7 \\
1930 & 2.9 & 13.2 & 30.5 & 40.7 & 11.8 & 0.9 \\
mean & 1.5 & 13.9 & 29.3 & 32.9 & 19.9 & 2.5 \\
\hline
\end{tabular}

Although the magnitude of population is far larger in the Kamtchatka district than in the Nemuro, the rates of recruitment may be nearly equal in both districts. Assuming that the rate of recruitment is 0.135 , the yield will be $600 \times 10^{3}$ crabs of large size with the fishing rate of 0.135 , as far as the population remains stationary.

Rkferences: Kajita, Y., 1932, Rep. Fish. Exper. Sta., Hokkaidô, no. 27 ; 1942 , Kaiyô Gyogyô, vol. 4, no. 4; Marukawa, H., 1933, Rep. Fish. Exp. Sta., Tokyô, no. 4; Suisan Kyoku (Bur. Fish.), 1938, Statistical Table of the northern Deep sea fisheries; Tauti, M., 1936, Bull. Japanese Soc. Sci. Fish., vol. 4, no. 4; Wang, Yi-Kuan, 1937; ibid., vol. 5, no. 6; Russell, E.S., 1939, Rapp. et Proc.-Verb., vol. 110. 